\title{
Prevalence of West Nile Virus Neutralizing Antibodies in Spain Is Related to the Behavior of Migratory Birds
}

\author{
GUILLERMO LÓPEZ, ${ }^{1}$ MIGUEL ÁNGEL JIMÉNEZ-CLAVERO, ${ }^{2}$ \\ CONCHA GÓMEZ TEJEDOR, ${ }^{3}$ RAMÓN SORIGUER, ${ }^{1}$ and JORDI FIGUEROLA ${ }^{1}$
}

\begin{abstract}
West Nile virus (WNV) is a bird flavivirus capable of infecting horses and humans that is transmitted by bloodsucking vectors. In Europe and Africa, sporadic infections and outbreaks causing human illness and deaths have occurred and have led to 2 mutually nonexclusive hypotheses regarding the circulation of WNV in Europe: (1) the occurrence of endemic sylvatic cycles that occasionally result in human or equine infection, or (2) sporadic seeding of WNV by migratory birds from areas where the virus is endemic in Africa or elsewhere that cause local epizootic foci and eventually lead to infection in humans. To investigate these 2 possibilities, we used a micro virusneutralization test to examine the prevalence of WNV neutralizing antibodies in 574 individuals belonging to 25 species of birds captured in spring 2004 in Seville (southern Spain). Trans-Saharan migrant species had both higher prevalences and antibody titers than resident and short-distance migrants. This result suggests that trans-Saharan migrants spend part of their life cycles in areas with greater circulation of WNV, or a closely related flavivirus, before their arrival in Spain. On the other hand, seroprevalences assessed in resident birds suggest a low level of WNV circulation in the studied locality. Aside from the question of local circulation, it thus seems that the risk for introduction of strains of WNV from Africa by migratory birds merits further field and experimental studies in Spain. Key Words: WNV_-Virus dispersal-Bird migration-Long-distance dispersal.
\end{abstract}

AU1 INTRODUCTION

W EST NiLE VIRUs (WNV) is an arbovirus (arthropod-borne virus) belonging to the Japanese encephalitis group (family Flaviviridae, genus Flavivirus). Virus transmission between hosts can occur both by means of a vector (usually mosquitoes or ticks, Chevalier et al. 2004, Lawrie et al. 2004) or, less commonly, by direct transmission (Banet-Noach et al. 2003). Although WNV causes illness and outbreaks of disease in humans and equines (Autorino et al. 2002, Durand et al. 2002, Del Giudice et al. 2004, Sanchez-Seco and Navarro 2005), the natural hosts of the virus are wild birds, which act as amplifying reservoirs (Zeller and Schuffenecker
2004). WNV normally causes an asymptomatic infection in Eurasian birds (Petersen and Roerigh 2001), and its presence in Eurasia has been known since 1958 (Bárdos et al. 1959). This situation differs greatly from the situation in the Americas, where the introduction of WNV in a single event in 1999 (Asnis et al. 2000) generated a fast and explosive spread over the whole continent which caused numerous outbreaks and mortality in humans, horses (Asnis et al. 2001, Blitvich et al. 2003), and wild native birds (Kramer and Bernard 2001). Despite WNV's origin in the Old World, it has been studied more intensively in North America since its introduction in 1999 than in Europe, as judged by the number of papers included in the ISI Web

\footnotetext{
${ }^{1}$ Estación Biológica de Doñana, CSIC, Seville, Spain.

${ }^{2}$ CISA-INIA, Valdeolmos (Madrid), Spain.

${ }^{3}$ Laboratorio Central de Veterinaria, Algete (Madrid), Spain.
} 
of Knowledge (129 vs. 693 up to November 2007). The intensity of circulation and the rapid spread of WNV in America, as well as the senAU2 $\rightarrow$ sibility of American birds to the disease, are thought to have converted migrant birds into important vectors for the transport of the virus throughout the continent. Peterson et al. (2003), for instance, found that migratory birds could explain the spread of WNV throughout North America. However, Rappole et al. (2003, 2006) did not find any basis to support this idea, as the dispersal patterns of WNV in North America are better explained by short-to-mediumdistance dispersive movements of resident birds. The known ecology and epidemiology of WNV in Europe have provided 2 potential hypotheses to explain the disease's outbreak dynamics (Hubálek 2000). First, a sylvatic circulation cycle could exist locally, which would maintain the virus in enzootic foci throughout the year and, under proper conditions, cause outbreaks in humans due to enhanced virus cir- culation. Second, migrant birds may act as virus carriers, repeatedly seeding the infection from areas where the virus is endemic in habitats suitable for the infection to progress in Europe in differing areas and years (Hubálek 2000, Malkinson et al. 2001, 2002, Malkinson and Banet 2002). To assess whether long-distance migrant birds are more exposed to WNV than resident birds, which would support the second of the 2 hypotheses, we carried out a seroprevalence study in small passerines. We hypothesized that long-distance migrant birds have a higher risk for exposure to WNV and thus may show higher seroprevalence than short-distance migrant or resident birds.

\section{MATERIALS AND METHODS}

We trapped 574 birds belonging to 25 different species (mainly passerines; Table 1) during prenuptial migration (March, April, and May)

Table 1. Species, Number of Sampled Individuals, and Titers for Individual Birds with WNV Neutralizing Antibodies Sampled Between March and May 2004 in Seville, Spain

\begin{tabular}{|c|c|c|c|c|c|c|c|c|}
\hline \multirow[b]{2}{*}{ Species } & \multicolumn{7}{|c|}{ Titers } & \multirow[b]{2}{*}{ Migratory status ${ }^{\mathrm{a}}$} \\
\hline & $\begin{array}{l}\text { Sampled } \\
\text { (n) }\end{array}$ & 20 & 40 & 80 & 160 & 320 & 640 & \\
\hline Acrocephalus scirpaceus & 5 & & & & & & & $\mathrm{~T}$ \\
\hline Alectoris rufa & 1 & & & & & & & $\mathrm{R}$ \\
\hline Carduelis carduelis & 10 & & & & & & & $\mathrm{R}$ \\
\hline Carduelis chloris & 26 & & & & & & & $\mathrm{R}$ \\
\hline Erithacus rubecula & 1 & & & & & & & M \\
\hline Ficedula hypoleuca & 19 & & & & & & & $\mathrm{~T}$ \\
\hline Galerida cristata & 2 & & & & & & & $\mathrm{R}$ \\
\hline Lanius senator & 17 & & & & 2 & & & $\mathrm{~T}$ \\
\hline Luscinia megarhynchos & 3 & & & & & & & $\mathrm{~T}$ \\
\hline Merops apiaster & 1 & & & & & & & $\mathrm{~T}$ \\
\hline Muscicapa striata & 5 & & & & & & & $\mathrm{~T}$ \\
\hline Oriolus oriolus & 1 & & & & & & & $\mathrm{~T}$ \\
\hline Passer domesticus & 79 & & & & & & & $\mathrm{R}$ \\
\hline Passer montanus & 1 & & & & & & & $\mathrm{R}$ \\
\hline Phoenicurus ochruros & 1 & & & & & & & $\mathrm{M}$ \\
\hline Phoenicurus phoenicurus & 2 & & 1 & & & & & $\mathrm{~T}$ \\
\hline Serinus serinus & 54 & & & & & & & $\mathrm{R}$ \\
\hline Streptopelia decaocto & 23 & & & & & & & $\mathrm{R}$ \\
\hline Sturnus unicolor & 1 & & & & & & & $\mathrm{R}$ \\
\hline Sylvia atricapilla & 59 & & & & & & & $\mathrm{M}$ \\
\hline Sylvia borin & 183 & 7 & 2 & 2 & 1 & 2 & 1 & $\mathrm{~T}$ \\
\hline Sylvia communis & 3 & & & & & & & $\mathrm{~T}$ \\
\hline Sylvia hortensis & 2 & & & & & & & $\mathrm{~T}$ \\
\hline Turdus merula & 74 & 3 & 1 & & & & & $\mathrm{R}$ \\
\hline Upupa epops & 2 & & & & & & & $\mathrm{M}$ \\
\hline
\end{tabular}

\footnotetext{
aEach species was scored as resident (R), short-distance migrant (M), or trans-Saharan migrant $(\mathrm{T})$.
} 
in 2004 in a forestry nursery near Seville city $\left(37^{\circ} 23^{\prime} \mathrm{N}, 5^{\circ} 57^{\prime} \mathrm{W}\right)$. We chose this place because of their proximity to human inhabited areas, where the potential for mosquito cofeeding in humans and birds is likely to be high. Additionally, passerines present high levels of virosis when infected with WNV and may be good candidates for virus amplification and dispersal (Komar et al. 2003, Owen et al. 2006). Birds were captured in 20 12-meter-long mist nets operating from sunrise to sunset. Individuals were marked with numbered aluminum rings and their body mass (to the nearest $0.1 \mathrm{~g}$ ) was recorded. For each individual we drew a blood sample from the jugular vein using $29 \mathrm{G}$ sterile insulin syringes (always less than 1\% of the body mass). The blood was placed in a vial, kept for several hours at ambient temperature $\left(15^{\circ} \mathrm{C}-25^{\circ} \mathrm{C}\right)$ to allow clotting, and then centrifuged for 10 minutes at $6000 \mathrm{rpm}$ in an Eppendorf Minispin centrifuge to separate the serum from the blood clots. The sera were frozen at $-20^{\circ} \mathrm{C}$ until subsequent analysis. The presence of WNV neutralizing antibodies was determined in each serum by a micro virusneutralization test (micro-VNT) in 96-well plates as previously described (Niedrig et al. 2006, Figuerola et al. 2007a). Serum samples were inactivated at $56^{\circ} \mathrm{C}$ for 30 minutes prior to analysis. Dilutions of test sera $(25 \mu \mathrm{L})$ were incubated for 1 hour at $37^{\circ} \mathrm{C}$ with 100 tissueculture infectious doses (TCID) 50 of $\mathrm{WNV}$ strain Eg101 in the same volume $(25 \mu \mathrm{L})$ in Eagle's medium (EMEM) supplemented with Lglutamine, nonessential amino acids, sodium pyruvate, penicillin $(100 \mathrm{U} / \mathrm{mL})$, and streptomycin $(100 \mu \mathrm{g} / \mathrm{mL})$. Then, $50 \mu \mathrm{L}$ of a suspension $\left(5 \times 10^{5}\right.$ cells $\left./ \mathrm{mL}\right)$ of Vero E6 cells was added to the same medium, along with fetal calf serum, to reach a final concentration of $5 \%$. The mixture was further incubated for 6 days at $37^{\circ} \mathrm{C}$ until a cytopathic effect (cpe) was observed in control wells containing 10 TCID $_{50}$ of virus. The screening of samples was performed at $1 / 10$ and $1 / 20$ dilutions of the tested sera (dilutions considered before the addition of virus, i.e., in a volume of $25 \mu \mathrm{L}$ ). Samples yielding positive neutralization (absence of cpe) at one or both of the dilutions tested were confirmed and further titrated by analyzing serial serum dilutions from $1 / 10$ to $1 / 640$. Controls for cytotoxicity in the absence of virus were included for every sample at 1/10 dilution. Cytotoxic samples were excluded from the analyses. The neutralizing serum titer was considered to be the highest value of the reciprocal serum dilution giving a complete absence of cpe. Birds were scored positive when neutralization at $1 / 20$ or higher dilutions occurred. The specificity of the VNT employed in our study has been analyzed previously using a panel of sera with specificity for different flaviviruses (WNV, yellow fever virus, dengue virus, and tick-borne encephalitis virus), and titers of 10 or higher were only detected in sera from WNV-infected individuals (Figuerola et al. 2007a). Additionally, previous studies have shown a higher specificity to WNV in neutralization tests run in parallel against Usutu virus (another bird Flavivirus), confirming that the flavivirus causing the immune reaction is more closely related to WNV than to other flaviviruses (Figuerola et al. 2007b). Each species was scored as resident, short-distance migrant (wintering in southern Europe or in Africa north of the Sahara), or trans-Saharan migrant (long-distance migrants wintering south of the Sahara) as per Cramp and Perrins (1994). WNV neutralizing antibody prevalence was analyzed with the GENMOD procedure (SAS Institute 2000a) in the SAS 9.1 statistical package. Deviances from the model were scaled with the square root of the ratio deviance/degrees of freedom to correct for overdispersion. Logtransformed values of antibody titers from individuals with antibodies were compared using a $t$-test for unequal variance groups with JMP 5.0 (SAS Institute 2000b).

\section{RESULTS}

For species with more than 20 individuals sampled, the prevalences ranged from $0 \%$ (Carduelis chloris, 95\% CI: 0\%-13.2\%; Passer domesticus, $0 \%-4.6 \%$; Serinus serinus, $0 \%-6.6 \%$; Streptopelia decaocto, 0\%-14.8\%; Sylvia atricapilla, $0 \%-6.1 \%$ ) to $8.1 \%$ (Sylvia borin, $4.7 \%-13.2 \%$ ). Intermediate prevalences were found in a resident species $(5.4 \%, 1.5 \%-13.3 \%$, Turdus merula), suggesting that local circulation of WNV exists. Antibody prevalence was related to migra- 
tion distance $\left(\chi^{2}=19.28, \mathrm{df}=2, p<0.0001\right)$. None of 63 sampled short-distance migrants presented WNV neutralizing antibodies. Antibodies to WNV were more prevalent in transSaharan (18 of 240 individuals, $4.5 \%-11.6 \%$ ) than in resident birds ( 4 of $271,0.4 \%-3.7 \%$, a posteriori least square means comparison, $\chi^{2}=$ 10.23, $\mathrm{df}=1, p=0.001$; Fig. 1A). Most of the sera from trans-Saharan birds correspond to $S$. borin, however, this is not likely to introduce a bias in the analyses because the GLM method used controls for differences in sample size and because a trend for higher prevalence in trans-
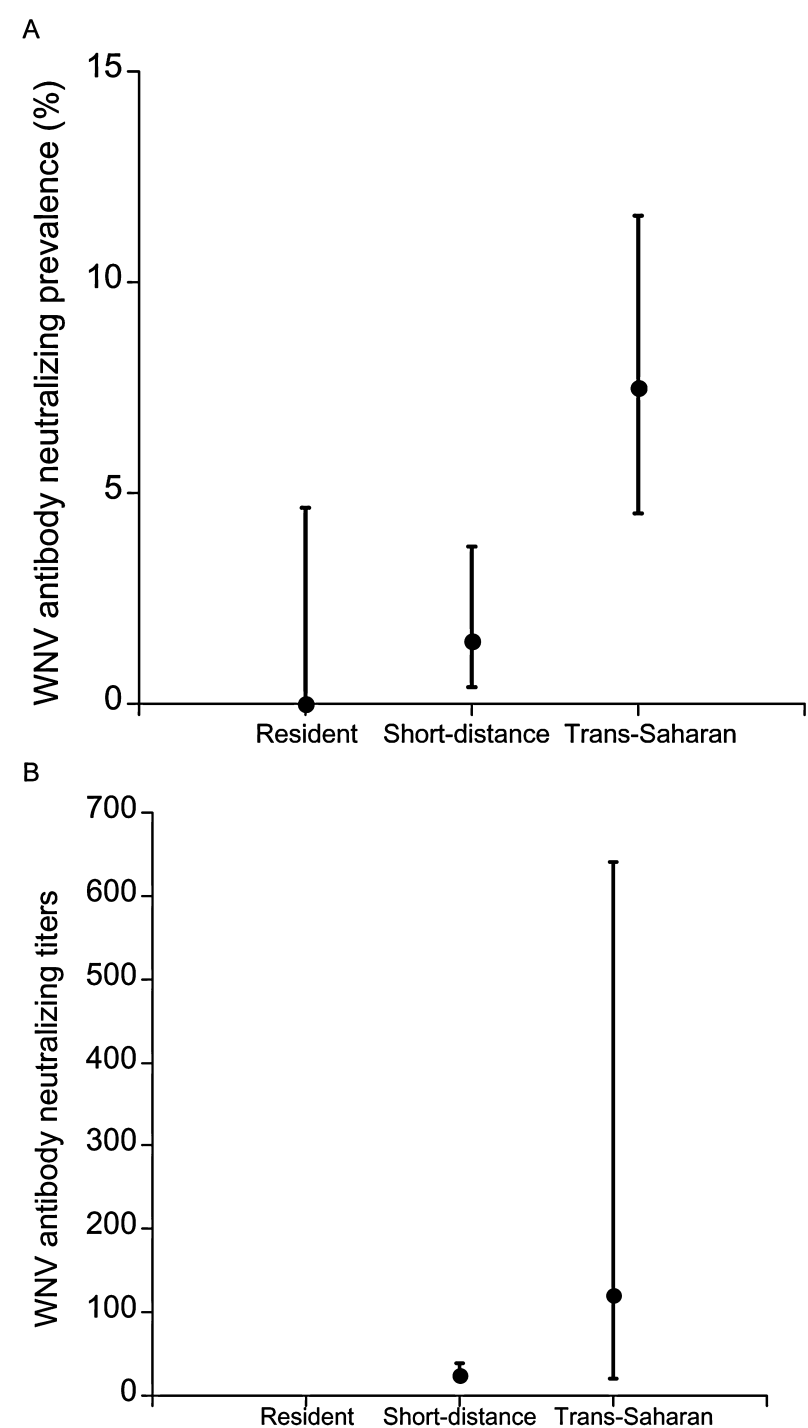

FIG. 1. Mean prevalence $\pm 95 \%$ confidence interval (A) and mean and range of titers (B) of antibodies against WNV in resident, short-distance migrant, and trans-Saharan migrant bird species trapped during spring migration in Spain.
Saharan species remains even when the analyses are repeated without $S$. borin $\left(\chi^{2}=5.56\right.$, $\mathrm{df}=2, p=0.06$ ). Antibody titers were also higher in trans-Saharan migrants than in resident birds $\left(\mathrm{t}_{17.54}=2.90, p=0.01\right.$; Fig. $\left.1 \mathrm{~B}\right)$.

\section{DISCUSSION}

Our results confirm that long-distance migrants are exposed during their migratory journeys and/or their winter stay in Africa to higher levels of WNV circulation, or a closely antigenically related flavivirus, than the levels found in their breeding grounds in Europe. In particular, species wintering south of the Sahara (Figs. 1 and 2) presented higher seroprevalences than species wintering in northern Africa and Spain. In addition, higher WNV antibody titers were found among trans-Saharan migrants, probably reflecting a recent (or repeated) exposure to the virus in individuals with higher titers. Although some studies done in captivity suggest that WNV antibodies remain detectable for more than a year (Gibbs et al. 2005), detailed analyses of animal serology both in the laboratory (Komar et al. 2003) and in the field (Figuerola et al. 2007b, Cabre et al. 2006) suggest a rapid reduction in antibody titers after exposure to the virus. In addition, both trans-Saharan and short-distance migrants captured in this study were on their journeys toward their breeding grounds (some in Spain, but also in northern Europe). There is no a priori reasons to expect differences in the geographical distribution of both groups during the breeding season, and both groups of species breed in sympatry and winter in allopatry. For this reason, we favor the hypothesis of a higher exposure to the virus in Africa rather than during the previous breeding season in Europe.

Among resident species, the case of Passer domesticus merits further discussion. Given the anthropogenic behavior of this species, it has often been proposed as a key species in the understanding of transmission to humans and as a focal species for WNV monitoring (Komar et al. 2001, Jourdain et al. 2007). However, none of the individuals sampled in our study presented antibodies, unlike the case of another 
FIG. 2. Wintering areas of trans-Saharan migrant species captured with WNV neutralizing antibodies between March and May 2004 in Seville, Spain: Ficedula hypoleuca (gray area), Sylvia borin (vertical lines), and Lanius senator (horizontal lines), based on Cramp and Perrins (1994).

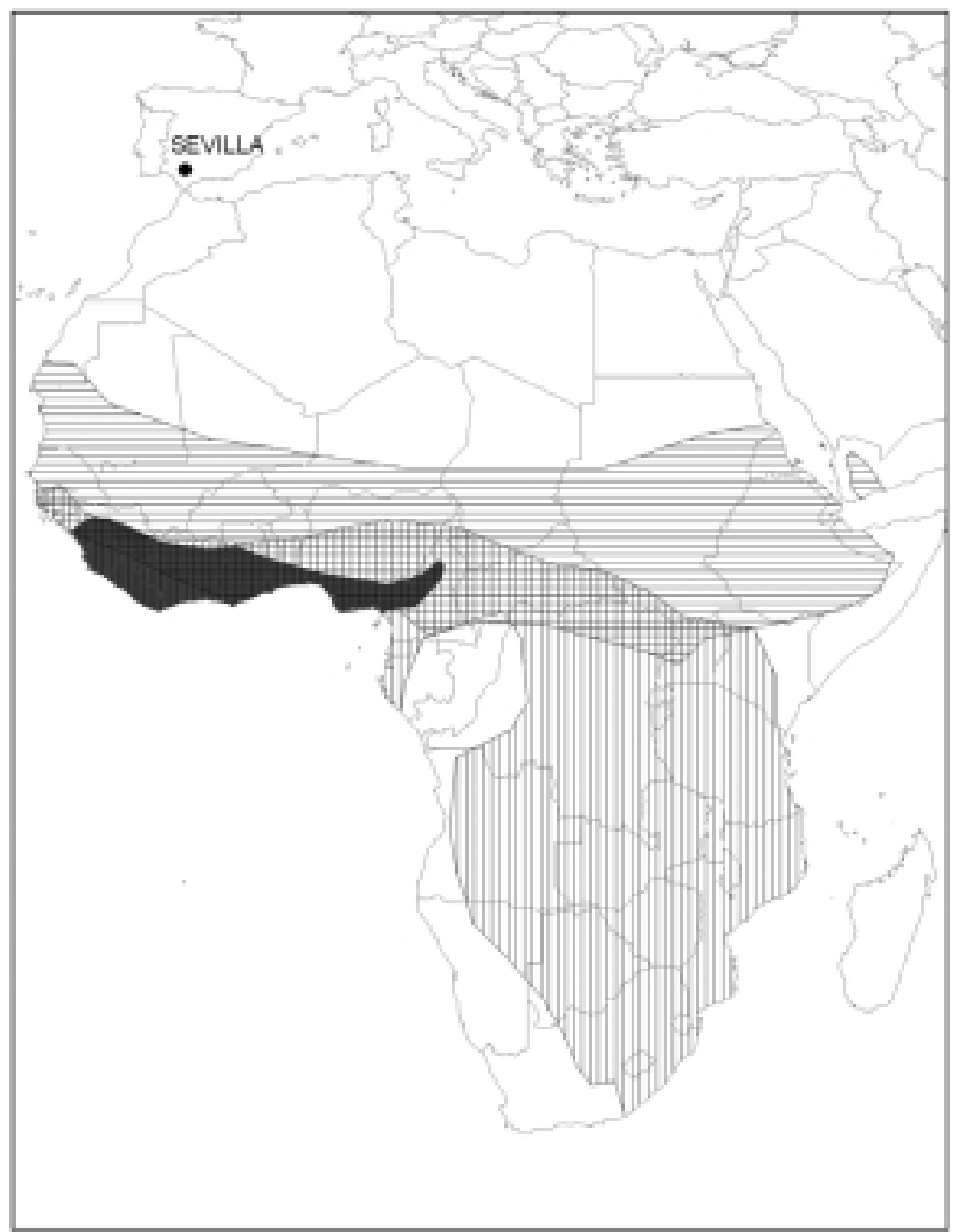

resident species of larger size, Turdus merula. Interestingly, recent detailed analyses of the dynamics of WNV in relation to bird ecology identified the conspecific species Turdus migratorius as a likely key species in explaining the transmission of WNV to humans in North America (Kilpatrick et al. 2006). Probably, we still lack the basic knowledge of the nature of the WNV-vector-host interactions needed to understand the regulatory factors of these interactions; thus, interspecific comparative studies are still necessary to understand the ecological factors regulating WNV-vector-host interactions.

Malkinson and Banet (2002) compared WNV strains isolated from birds in eastern Europe that had arrived from Africa with others isolated in Africa and suggested that migratory routes can explain the occurrence of West Nile foci in Europe. The winter distributions of the
3 species of trans-Saharan migrant passerines that show seropositivity for WNV neutralizing antibodies overlap in a region of Africa that includes parts of Liberia, Ivory Coast, Ghana, Togo, Benin, Nigeria, and Cameroon. The highest seroprevalence $(8.2 \%)$ was found for Sylvia borin, a species with a geographically wide winter distribution in Africa extending from $13^{\circ} \mathrm{N}$ to $35^{\circ} \mathrm{S}$. A recent serosurvey of horses in subSaharan Africa reporting a high seroprevalence of WNV neutralizing antibodies (up to $97 \%$ in some countries, Cabre et al. 2006) further supports these conclusions. While it is true that some birds may be infected while on migration, the low seroprevalence of antibodies in shortdistance and resident birds suggests that exposure to WNV occurs mainly south of the Sahara.

Do our results imply that there is a high risk for infection by WNV caused by the arrival of 
migratory birds? While this is a possibility, we consider that it is highly unlikely. First, we have previously shown that local circulation of WNV occurs in Spain without necessarily leading to illness among humans (Figuerola et al. 2007b), thus supporting the hypothesis that WNV-or a closely related cross-reacting flavivirus-remains essentially undetected and sylvatic in Europe. Second, for successful longdistance dispersal of WNV by migratory birds, a successive series of highly unlikely events must occur over a short period of time: (1) a WNV-infected mosquito must infect an immunologically naïve bird; (2) the bird then must survive the infection, accumulate fat reserves, and cross the Sahara in a continuous or intermittent flight of 40 hours over $2000 \mathrm{~km}$ of inhospitable terrain (Schmaljohann et al. 2007); (3) the bird must then be bitten after arrival by a susceptible vector while still viremic (viremia lasts less than 7 days in birds; see Komar et al. 2003); and, finally, (4) the infected vector must then feed and infect other susceptible birds in the new locality. Most of the parameters needed to calculate the likelihood of this process are still unknown. Recently, Owen et al. (2006) have demonstrated that individuals of 2 passerine species show migratory restlessness while still viremic, although no information is available yet on the impact of WNV on the capacity of birds to accumulate energetic reserves and perform serious exercise while viremic, or on the effect of the stress produced by migration on viremia. The parameterization of the different factors that affect transmission rates of WNV at local and long-distance scales is essential if we are to understand the real role of migratory and resident bird species in the dispersal dynamics of the virus.

\section{ACKNOWLEDGMENTS}

The Spanish Ministry of Health via the Thematic Research Net 'EVITAR' funded our research. EDEN (Emerging Diseases in a changing European Environment), FP6, RNM 118, and RNM 157 (PAI, Junta de Andalucía) also partially funded this study. Help from Oscar González, Manuel Vázquez, Beatriz Sánchez, and Ernesto García was essential in the cap- turing and manipulation of birds. Alberto Álvarez, Alicia Cortés, Ángel Mejía, Ara Villegas, Beatriz Fernández, Carmen Gutiérrez, Chari Terceño, Cristina Sánchez, Elena Fierro, Enrique Sánchez, Esteban Serrano, Francisco Miranda, Grego Toral, Inma Cancio, Francisco Jamardo, Miguel Carrero, Manuel Sánchez, Joaquín Díaz, José Antonio Sánchez, Mari Carmen Roque, Olga Jiménez, Pedro Sáez, Rafael Reina, and Samuel del Río also assisted during the fieldwork.

\section{REFERENCES}

Asnis, D, Conetta, R, Teixeira, A, Waldman, G, et al. The West Nile virus outbreak of 1999 in New York: the Flushing Hospital experience. Clin Infect Dis 2000; 30:413-418.

Asnis, DS, Conetta, R, Waldman, G, Teixeira, AA. The West Nile virus encephalitis outbreak in the United States (1999-2000). From Flushing, New York, to beyond its borders. Ann NY Acad Sci 2001; 951:161-171.

Autorino, GL, Battisti, A, Deubel, V, Ferrari, G, et al. West Nile virus epidemic in horses, Tuscany region, Italy. Emerg Infect Dis 2002; 8:1372-1378.

Banet-Noach, C, Simanov, L, Malkinson, M. Direct (nonvector) transmission of West Nile virus in geese. Avian Pathol 2003; 32:489-494.

Bárdos, V, Adamcová, J, Dedei, S, Gjini, N, et al. Neutralizing antibodies against some neurotropic viruses determined in human sera in Albania. J Hyg Epidemiol Microbiol Immunol 1959; 3:277-282.

Blitvich, BJ, Fernandez-Salas, I, Contreras-Cordero, JF, Marlenee, NL, et al. Serologic evidence of West Nile virus infection in horses, Coahuila State, Mexico. Emerg Infect Dis 2003; 9:853-856.

Cabre, O, Grandadam, M, Marié, J-L, Gravier, P, et al. West Nile virus in horses, sub-Saharan Africa. Emerg Infect Dis 2006; 12:1958-1960.

Chevalier, V, de la Rocque, S, Baldet, T, Vial, L, et al. Epidemiological processes involved in the emergence of vector-borne diseases: West Nile fever, Rift Valley fever, Japanese encephalitis and Crimean-Congo haemorrhagic fever. Rev Sci Tech 2004; 23:535-555.

Cramp, S, Perrins, CM. Handbook of the Birds of Europe, the Middle East and North Africa. The Birds of the Western Paleartic. Oxford: Oxford University Press; 1994.

Del Giudice, P, Schuffenecker, I, Vandenbos, F, Counillon, E, et al. Human West Nile virus, France. Emerg Infect Dis 2004; 10:1885-1886.

Durand, B, Chevalier, V, Pouillot, R, Labie, J, et al. West Nile virus outbreak in horses, southern France, 2000: results of a serosurvey. Emerg Infect Dis 2002; 8:777782.

Figuerola, J, Jimenez-Clavero, M, Rojo, G, Gómez-Tejedor, C, et al. Prevalence of West Nile virus neutraliz- 
ing antibodies in colonial aquatic birds in southern Spain. Avian Pathol 2007a; 36:209-212.

Figuerola, J, Soriguer, R, Rojo, G, Gómez-Tejedor, C, et al. Seroconversion in wild birds and local circulation of West Nile virus, Spain. Emerg Infect Dis 2007b; 13:1915-1917.

Gibbs, SEJ, Hoffman, DM, Stark, LM, Marlenee, NL, et al. Persistence of antibodies to West Nile virus in naturally infected rock pigeons (Columba livia). Clin Diagn Lab Immunol 2005; 12:665-667.

Hubálek, Z. European experience with the West Nile virus ecology and epidemiology: could it be relevant for the New World? Viral Immunol 2000; 13:415-426.

Jourdain, E, Toussaint, Y, Leblond, A, Bicout, DJ, et al. Bird species potentially involved in introduction, amplification, and spread of West Nile virus in a Mediterranean wetland, the Camargue (southern France). Vector-Borne Zoonotic DIs 2007; 7:15-33.

Kilpatrick, AM, Daszak, P, Jones, MJ, Marra, PP, et al. Host heterogeneity dominates West Nile virus transmission. Proc Biol Sci 2006; 273:2327-2333.

Komar, N, Panella, NA, Burns, JE, Dusza, SW, et al. Serologic evidence for West Nile virus infection in birds in the New York City vicinity during an outbreak in 1999. Emerg Infect Dis 2001; 7:621-625.

Komar, N, Langevin, S, Hinten, S, Nemeth, N, et al. Experimental infection of North American birds with the New York 1999 strain of West Nile virus. Emerg Infect Dis 2003; 9:311-322.

Kramer, LD, Bernard, KA. West Nile virus infection in birds and mammals. Ann NY Acad Sci 2001; 951:84-93.

Lawrie, CH, Uzcategui, NY, Gould, EA, Nuttall, PA. Ixodid and argasid tick species and West Nile virus. Emerg Infect Dis 2004; 10:653-657.

Malkinson, M, Banet, C. The role of birds in the ecology of West Nile virus in Europe and Africa. Curr Top Microbiol Immunol 2002; 267:309-322.

Malkinson, M, Weisman, Y, Pokamunski, S, King, R, et al. Intercontinental transmission of West Nile virus by migrating white storks. Emerg Infect Dis 2001; 7:540.

Malkinson, M, Banet, C, Weisman, Y, Pokamunski, S, et al. Introduction of West Nile virus in the Middle East by migrating white storks. Emerg Infect Dis 2002; 8:392-397.

Niedrig, M, Linke, S, Zeller, H, Drosten, C. First international proficiency study on West Nile virus molecular detection. Clin Chem 2006; 52:1851-1854.
Owen, J, Moore, F, Panella, N, Edwards, E, et al. Migrating birds as dispersal vehicles for West Nile virus. EcoHealth 2006; 3:79-85.

Petersen, LR, Roerigh, JT. West Nile virus: a reemerging global pathogen. Rev Biomed 2001; 12:208-216.

Peterson, AT, Vieglais, DA, Andreasen, JK. Migratory birds modeled as critical transport agents for West Nile virus in North America. Vector-Borne Zoonotic Dis 2003; 3:27-37.

Rappole, JH, Hubalek, Z. Migratory birds and West Nile virus. J Appl Microbiol 2003; 94:47S-58S.

Rappole, JH, Compton, BW, Leimgruber, P, Robertson, J, et al. Modelling movement of West Nile virus in the Western hemisphere. Vector-Borne Zoonotic Dis 2006; 6:128-139.

Reed, LJ, Muench, H. A simple method of estimating fifty percent endpoints. Am J Hyg 1938; 27:493-497.

Sanchez-Seco, MP, Navarro, JM. Infections due to Toscana virus, West Nile virus, and other arboviruses of interest in Europe. Enferm Infecc Microbiol Clin 2005; 23:560-568.

SAS Institute, Inc. SAS/STAT Software: User's Guide. Cary, NC: SAS Institute, Inc.; 2000a.

SAS Institute, Inc. JMP User's Guide. Cary, NC: SAS Institute, Inc.; 2000b.

Schmaljohann, H, Liechti, F, Bruderer, B. Songbird migration across the Sahara: the non-stop hypothesis rejected! Proc Biol Sci 2007; 274:735-739.

Weintgartl, HM, Drebot, MA, Hubalek, Z, Halouzka, J, et al. Comparison of assays for the detection of West Nile virus antibodies in chicken serum. Can J Vet Res 2003; 67:128-132.

Zeller, HG, Schuffenecker, I. West Nile virus: an overview of its spread in Europe and the Mediterranean Basin in contrast to its spread in the Americas. Eur J Clin Microbiol Infect Dis 2004; 23:147-156.

Address reprint requests to: Dr. Jordi Figuerola

Department of Wetland Ecology

Estación Biológica de Doñana, CSIC Avda. Maria Luisa, s/n 41013 Seville, Spain

E-mail: jordi@ebd.csic.es 


\section{LÓPEZ}

AU1

Please cite these Refs. in text OR delete from Ref. list.-Reed \& Muench 1938; Weintgartl et al., 2003.

AU2

OK or "sensitivity" meant here?

AU3

Please cite or delete.

AU4

Please cite or delete.

AU5

column head ok? 